\title{
Ethnobotanical survey of indigenous leafy vegetables in Ehlanzeni District of the Mpumalanga Province, South Africa
}

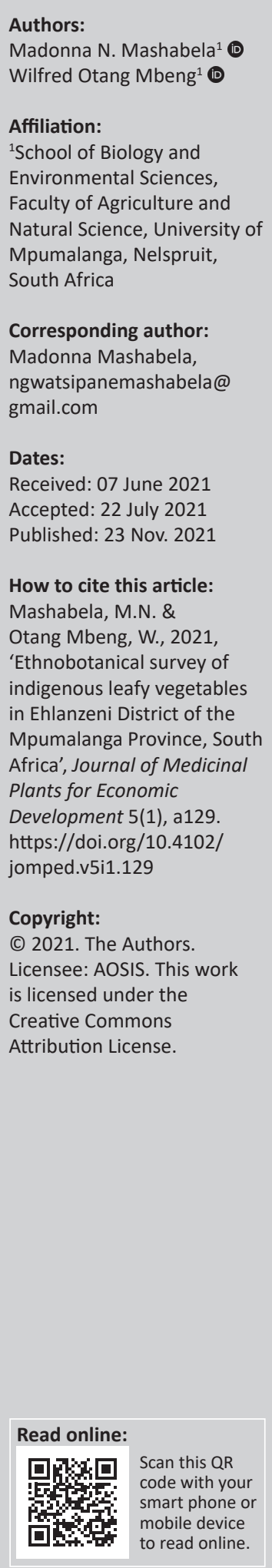

Background: There is a high loss of indigenous knowledge, resulting in negative effects on the health and lives of cultural people living in poor communities mostly in the rural areas, hence, an urgent need for indigenous knowledge conservation.

Aim: This study is aimed at presenting the potentials of leafy indigenous vegetables as an essential source of food and nutrition for poor communities. We argue that through knowledge transfer, these species have a chance of being revitalised and used, thereby conserving plant biodiversity while ensuring food and nutrition security.

Setting: An ethnobotanical survey was conducted in the Ehlanzeni District of the Mpumalanga Province, South Africa, to uncover and document the indigenous leafy vegetables (ILVs) from the area as well as to evaluate the community's indigenous vegetable knowledge and utilisation state.

Methods: Using a structured questionnaire, 95 respondents were interviewed. Older women were particularly targeted since they are the repositories of ethnobotanical information related to ILVs.

Results: The study revealed 17 indigenous leafy vegetable species from 10 families. About $85 \%$ of the ILVs cited possessed medicinal properties. The most common means of preservation was sun-drying, although consumption of vegetables in their fresh state was most preferred.

Conclusion: High blood pressure was cited to be treated by most of the ILVs; therefore, there is a need to include these vegetables in our daily diets.

Keywords: leafy indigenous vegetable; ethnobotany; South Africa; conservation; Mpumalanga Province.

\section{Introduction}

The inclusion and consumption of indigenous leafy vegetables (ILVs) in many cultures of the world is as old as the story of civilisation. Several studies in taxonomic classification and chemical compositions of ILVs have been conducted (Pieroni et al. 2002). However, their outcomes mainly report the nutritional properties and medicinal uses of these ILVs. These ILVs grow in the wild without the need for cultivation or management (Tardío, Pardo-de-Santayana \& Morales 2006). The relationship between ILV food uses and their medicinal uses are inseparable. In Sub-Saharan Africa, ILVs are a contributor of significance when it comes to the socio-economic well-being of different communities. Furthermore, their roles as culinary in countries such as South Africa, Nigeria, Zimbabwe, Ghana, Kenya and other parts of the world have been documented (Adebooye \& Opabode 2004).

Ethnobotanical studies are the important link existing between plants and people in a specific ecosystem. This relates to the use of plants by human beings for their benefits as medicines or food for their well-being. Vegetables are consumed in the form of leaves, pods, seeds and fruits. Indigenous leafy vegetables are often referred to as the traditional leafy vegetables or crop species that are distinct to a locality or region. They form an important and essential portion of daily diets, and are consumed as a relish to complement staple dishes, mainly carbohydrates. These species are a significant source for the supplementation of minerals, micronutrients, phytochemicals and vitamins, especially in vegetarian diets (Odhav et al. 2007). They are very adaptive, resilient and can survive adverse climates, they grow easily in the wild and most of them do not need to be formally cultivated, as they are readily available in the fields (Raghuvanshi, Singh \& Singh 2001). However, 
there is a high erosion of people's knowledge of indigenous vegetables because of the low value attached to them.

Similar to other knowledge systems that are considered Indigenous Knowledge System (IKS), ILVs knowledge is gradually declining and this needs drastic and immediate preservation efforts. There is an obvious reduction in consumption of ILVs in South African rural communities because of the introduction of exotic leafy vegetables such as spinach and cabbage. Limited nutritional studies have already been conducted on ILVs. However, there is a lack of interest from people about the ILVs. Researchers therefore need to genomically (Genomics) identify and document these species and deposit them in a gene bank, propagating their preservation (Adebooye \& Opabode 2004). The elderly are usually the repositories of indigenous knowledge, which is then passed down through generations without documentation, thereby putting indigenous knowledge at risk of loss to posterity after their demise. The youths generally resist indigenous knowledge because of the negative perceptions associated with the knowledge. Perceptions of this knowledge being outdated and failure to live in modern times make this knowledge very unpopular amongst the youths. Singh and Arora (1978) reported that many rural populations of the world meet part of their nutritional requirements by the consumption of different leafy vegetables. Of all the 150 food plants consumed daily by people, about 115 are indigenous species (Kiambi \& Atta-Krah 2003).

The consumption of ILVs has been reported to have many beneficial effects, which include inhibition of some agerelated degenerative diseases like stroke and arteriosclerosis. Furthermore, Kimiywe et al. (2007) stated that many ILVs have been associated with curing certain diseases such as diabetes, chest pains, stomach ache. Apart from serving as complementary foods and medicines, ILVs offer an alternative source of income to poor resource communities. Indigenous leafy vegetables could be of help in combating the menace of malnutrition and hunger, which are major challenges faced by millions of Sub-Saharan African populations. Obel-Lawson (2005) has reported the positive effects of the consumption of ILVs on the health, nutrition and economic wellbeing of both urban and rural population. There has been gradual negligence of most ILVs with medicinal and culinary uses over the years, which has resulted in their underutilisation. Civilisation, inadequate information on therapeutic benefits and lack of information on their nutritional benefits are the most critical factors contributing towards the underutilisation of these ILVs in many communities (Shei 2008). Because of their local availability, ILVs are inexpensive, especially for low-income earners. They are good sources of important nutrients that play substantial roles in diets, food security, and serve as supplements for the management of illnesses associated with nutrition (Odhav et al. 2007).

The decline in ILV recognition and utilisation is a global phenomenon regardless of their high nutritional status.
Globally, these species are viewed as notorious weeds which must be exterminated with pesticides to allow major crops to grow. There is also an over-reliance on exotic species such as spinach that are widely and commercially cultivated (Vorster \& Van Rensburg 2005). Proper documentation, the mode of preparation and preservation as well as method of propagation are some of the information that may be lost in time. The loss of plant diversity presents a danger in the loss of nutraceutical species, which will potentially exert negative effects on posterity's well-being and health (Ayodele 2005). The biodiversity conservation of these species, to ensure their availability for future generations, is therefore important. Ethnobotanical surveys such as the present study are one of the first steps in conservation and ensuring sustainable utilisation of these important resources (Kumar 2013). Therefore, in the present study, we identify and document the leafy indigenous vegetables growing in the wild in Mpumalanga Province of South Africa and determine the conservation methods that can be employed for their preservation.

\section{Materials and methods Description of the study area}

The current study was conducted in the Ehlanzeni District municipal in Mpumalanga Province, South Africa. Mpumalanga Province which houses the Ehlanzeni District is located at latitude $29^{\circ} 48^{\prime} 46^{\prime \prime} \mathrm{S}$ and longitude $30^{\circ} 38^{\prime} 11^{\prime \prime} \mathrm{E}$, is the second-smallest province in South Africa after Gauteng. It is situated in the north-eastern part of the country, bordering Mozambique and Eswatini to the east. It also borders Gauteng, Limpopo, KwaZulu-Natal and Free State within South Africa. The Ehlanzeni District is divided into Nkomazi, Bushbuckridge, Umjindi, Mbombela and Thaba Chweu local municipalities (see Figure 1). The population consists of $4.45 \%$ White (82 600), 0.55\% Asian (10 200), 94.36\% African (1.75 million) and $0.64 \%$ mixed race people (11 800) (Mashile, Tshisikhawe \& Masevhe 2018; SSA 2008).

Siswati (30\%) (a language of the Eswatini a neighbouring country) is the most dominant language in Mpumalanga, while $26 \%$ of the inhabitants speak isiZulu, $11.6 \%$ Xitsonga, $10.3 \%$ isiNdebele and $21.2 \%$ Northern Sotho.

\section{Ethnopharmacological investigation}

The method of Flyman and Afolayan (2006) was used to collect the information in this survey. Village interviews were conducted with a well-structured questionnaire. Older women were particularly targeted since they are the repositories of ethnobotanical information related to ILVs. The information gathered included the local names, various uses, modes of preparation, and preservation as well as conservation and season of availability, and general question such as the local names of the ILVs. Interviewees numbering was 95 (56 females and 39 males), aged between 19 and 89 years, were interviewed in four locations (Godini, Kanyamazane, Mangweni and Matsulu) of the Enhlanzeni District, between October and November 2020. 


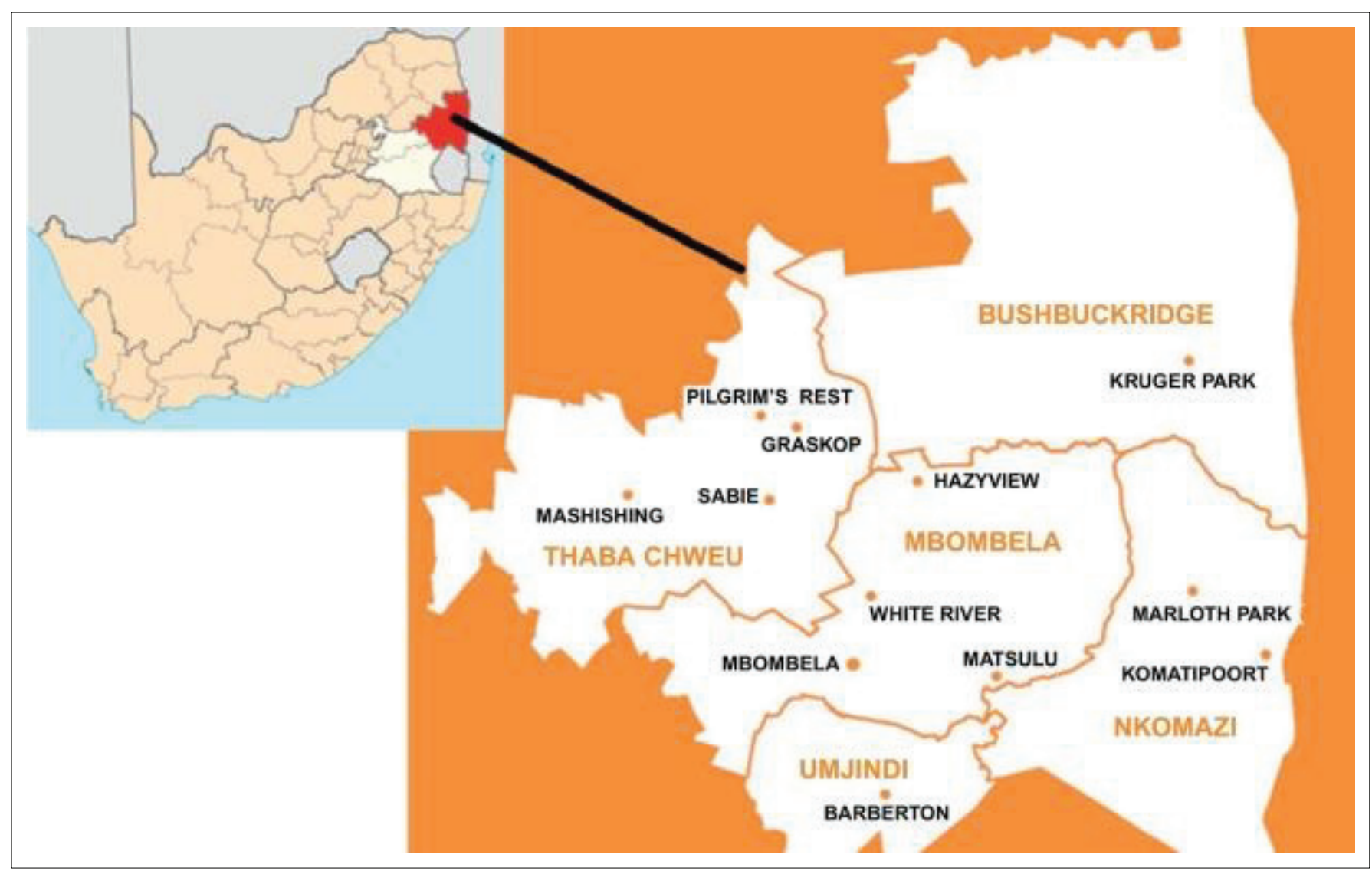

Source: Ntiwane, B.C., 2012, 'A critical analysis of the incorporation of environmental issues into land use and planning instruments of selected municipalities of the Ehlanzeni District Municipality', Doctoral dissertation, North-West University

FIGURE 1: Ehlanzeni local municipalities map.

Using the convenience sampling technique, participants were selected with a particular focus on those who regularly use ILVs. In addition, both male and female members of the community were interviewed to ensure a balanced report representing the whole community (Singh, Kumar \& Tewari 2012).

Language constraints were overcome by conducting the interviews in the local Siswati language with the help of a translator who was fluent in both the local language and English. The questions targeted the local names of the ILVs, the parts of the plant that are used, preparation and preservation/conservation methods, medicinal uses, and their thoughts on possible causes of decline in ILV utilisation and knowledge. To validate the identified plant species/ ILVs, responses of two or more respondents were compared and validated if they coincided on the same plant, regardless of the methods of preparation (Martínez \& Barboza 2010). The results of the study are presented in Table 1 . The inclusion of unique data in Table 1 occurred when the data were supported by previous ethnobotanical studies of the area from literature. All the plants that were collected were authenticated at the Botany Department at University of Mpumalanga using flouristic works of South Africa (Cilliers et al. 2021). Voucher spacemen were authenticated and deposited at the Herbarium in the Botany Department at the University of Mpumalanga.
TABLE 1: Respondents' demographic characteristics.

\begin{tabular}{lcc}
\hline Demographics & Total & $\mathbf{\%}$ \\
\hline Age & & \\
Godini & - & 39.4 \\
Kanyamazane & - & 43.0 \\
Mangweni & - & 53.2 \\
Matsulu & - & 51.9 \\
Gender & & \\
Male & 39 & 41.05 \\
Female & 56 & 58.95 \\
Employment status & & \\
Employed & 18 & 18.75 \\
Not employed & 55 & 57.29 \\
Pensioner & 16 & 16.67 \\
Self-employed & 7 & 7.29
\end{tabular}

\section{Data analysis}

The use-value, as well as the informant consensus factor (ICF), were used to analyse the reported data. These values were calculated as follows:

$\mathrm{UV}=\sum \mathrm{u} / \mathrm{n}$

[Eqn 1]

Where:

- $\mathrm{UV}=$ relative use-value of a species

- $\mathrm{u}=$ number of citations per species

- $n=$ number of informants 
TABLE 2: Indigenous leafy vegetables for medicinal use in four villages of Mpumalanga Province.

\begin{tabular}{|c|c|c|c|c|c|c|c|}
\hline \multirow[t]{2}{*}{ Botanical name } & \multirow[t]{2}{*}{ Family } & \multirow[t]{2}{*}{ Local name } & \multirow{2}{*}{$\begin{array}{l}\text { Voucher } \\
\text { specimen }\end{array}$} & \multirow{2}{*}{$\begin{array}{l}\text { Frequency } \\
\text { of citation }\end{array}$} & \multirow[t]{2}{*}{ Habit } & \multicolumn{2}{|c|}{ Medicinal use } \\
\hline & & & & & & No & Yes \\
\hline Abelmoschus esculentus & Malvaceae & Mandade & MN01 & 3 & Shrub & 3 & - \\
\hline Amaranthus $L$. & Amaranthaceae & Imbuya & MNO2 & 42 & Herb & 20 & 22 \\
\hline Beta vulgaris & Amaranthaceae & Macembe abeetroot & MNO3 & 1 & Herb & 1 & - \\
\hline Bidens pilosa $L$. & Asteraceae & Chuchuza & MNO4 & 33 & Herb & 27 & 6 \\
\hline Brassica oleracea & Brassicaceae & Makhovu & MN05 & 1 & Herb & 1 & - \\
\hline Phaseolus vulgari & Fabaceae & Bontshisi & MNO7 & 1 & Herb & 1 & - \\
\hline Citrullus lanatus & Cucurbitaceae & Umbhidvo wetintsanga & MN08 & 52 & Herb & 36 & 16 \\
\hline Cleome gynandra & Cleomaceae & Bangani & MN09 & 5 & Herb & 2 & 3 \\
\hline Colocasia esculenta & Araceae & Mathapa & MN10 & 8 & Herb & 2 & 6 \\
\hline Corchorus olitorius & Malvaceae & Gushe & MN11 & 1 & Herb & 1 & - \\
\hline Ipomoea batatas & Convolvulaceae & Macembe abhatata & MN11 & 3 & Herb & 3 & - \\
\hline Lagenaria siceraria & Cucurbitaceae & Mbhidvo & MN12 & 1 & Herb & 1 & - \\
\hline Momordica balsamina & Cucurbitaceae & Inkaka & MN14 & 66 & Herb & 8 & 58 \\
\hline Sonchus oleraceus (L.) L & Asteraceae & Ingabe & MN15 & - & Herb & 6 & 3 \\
\hline Vigna unguiculata (L.) & Fabaceae & Tindlubu & MN16 & 1 & Herb & - & 1 \\
\hline
\end{tabular}

\section{Intellectual property agreement}

The interviewees gave their full consent voluntarily to participate in the ethnobotanical survey. As part of this consent, the participants were free to withdraw from the study at any time without repercussions as prescribed by Langlois-Klassen, Kipp and Rubaale (2008). Furthermore, a verbal contract was established that the results of the study were for the benefit of their community and the country, and shall lead to the preservation of their indigenous knowledge and plant biodiversity. It was further clarified to the participants that the results would not be used for commercial purposes or turned into a profit.

\section{Ethical considerations}

The study was based on human research participants. The authors are pleased to inform that the Chairperson has on behalf of the University of Mpumalanga's Research Ethics Committee, approved ethical clearance of the abovementioned study (Ethical clearance number: UMP/ Ngwatshipane/FANS/2021).

\section{Results}

\section{Socio-demographic information}

The socio-economic and demographic characteristics of the interviewees including their level of indigenous knowledge on ILVs species are reported in this section. Gender, age, employment status and level of indigenous knowledge were analysed. A total of 95 informants, from four different study areas: Godini, Kanyamazane, Mangweni and Matsulu villages participated in the present study. The participants were aged between 19 and 89 years with a mean age of 39.4, 43, 53.2 and 51.9, comprising 41.05\% (39) male and 58.95\% (56) female (Table 1). Only $57.29 \%$ (55) of the respondents who were knowledgeable on the ILVs were unemployed, $18.75 \%$ (18) were employed, $16.67 \%$ (16) were pensioners, and $7.29 \%$ (7) were self-employed.

\section{Diversity of indigenous leafy vegetables utilised in four villages}

Determining plant utilisation would help establish the diversity of use and give an indication of the extent of indigenous knowledge associated with this use. Table 2 shows a list of the most known ILVs in four different areas of Mpumalanga Province with their scientific names, arranged in chronological alphabetical order. The number of informants is also given, including the plant's local name(s), medicinal uses and habit. The study revealed that 17 plant species from 15 genera as reported by 95 respondents are used for medicinal purposes in the Province.

\section{Medicinal and nutritional uses of indigenous leafy vegetables, plant part used and mode of preparation}

From all the ILVs discovered in the present study areas, about $85 \%$ are used for prevention, treatment, or management of various ailments. About 29 different diseases that were reported to be treated by the ILVs were found in four villages of the Province. For instance, Inkaka (Momordica balsamina) (66 citations) had the highest number of citations and is used for treating gallbladder diseases (as indicated by $27.27 \%$ of respondents) and high blood pressure $(19.70 \%$ of the respondents). High blood pressure was cited to be treated by most of the ILVs identified. However, because most of the ILVs are used as both food and medicine, they have not been formally categorised as foods or medicine in comparison with the exotic species, which are formally categorised as foods. Results from the current study showed that the leaves of indigenous vegetables are cooked and eaten as a relish with pap (a thick porridge made from maize mealie meal), made into a salad, eaten raw and fresh or mixed with mealie rice and taken with tea (Figure 2). Cooking the leaves and eating with pap (66.1\%) was the most common usage, while usage for tea was the least. From the present study, the leaves are the most used part notwithstanding the occasional consumption of fruits, flowers, bulbs tubers and/or seeds. 
The use of the plant parts decreased in the order: leaves $>$ fruits $>$ tubers $>$ seeds $>$ bulbs. The leaves were cooked and eaten with pap. Four methods of preparations of ILVs for medicine were revealed in the present study. Boiling the leaves and drinking the water (83 citations) was the most dominant method, followed by chopping and soaking in warm water (8 citations), grinding and soaking in water and lastly, slightly boiling (1 citation each) (Figure 3).

\section{Method of preservation and indigenous practices to conserve indigenous leafy vegetables}

Out of the 17 plant species that were mentioned in the survey as ILVs, $90 \%$ of them can be preserved by drying the leaves

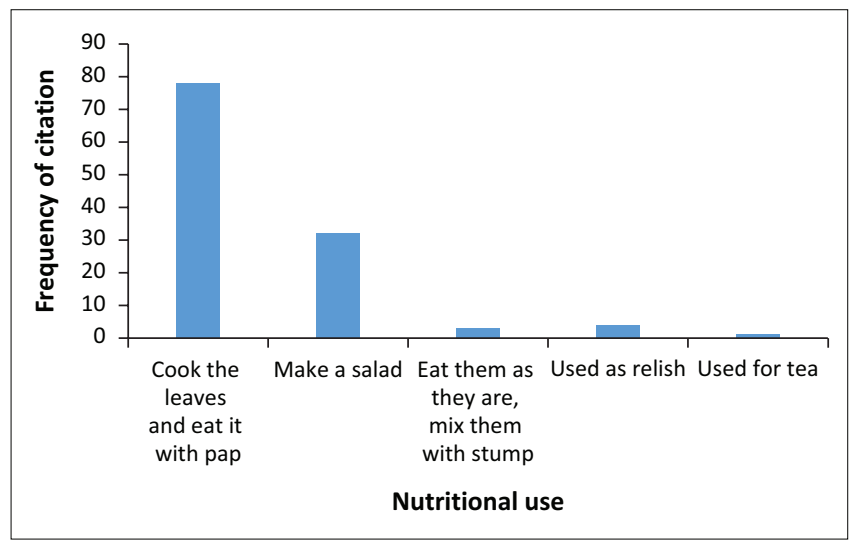

FIGURE 2: Nutritional use of indigenous leafy vegetables.

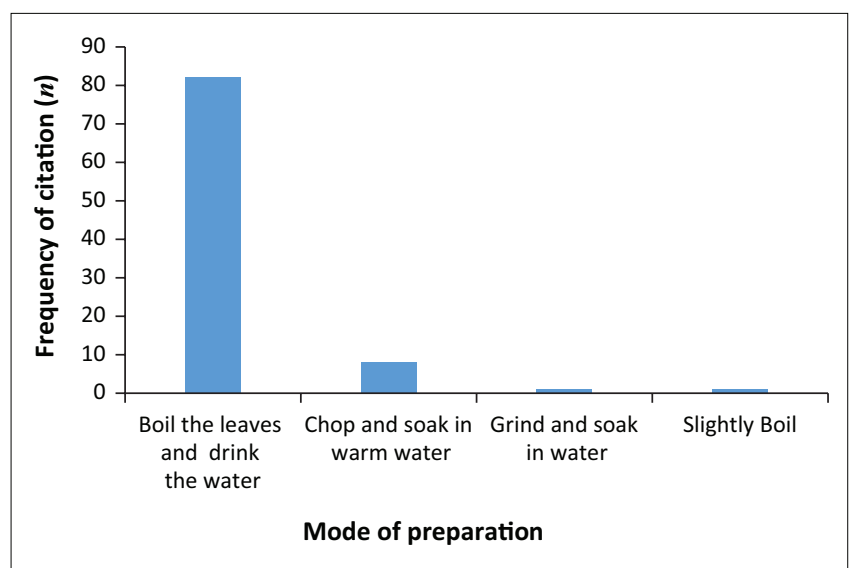

FIGURE 3: Mode of preparation for indigenous leafy vegetables.

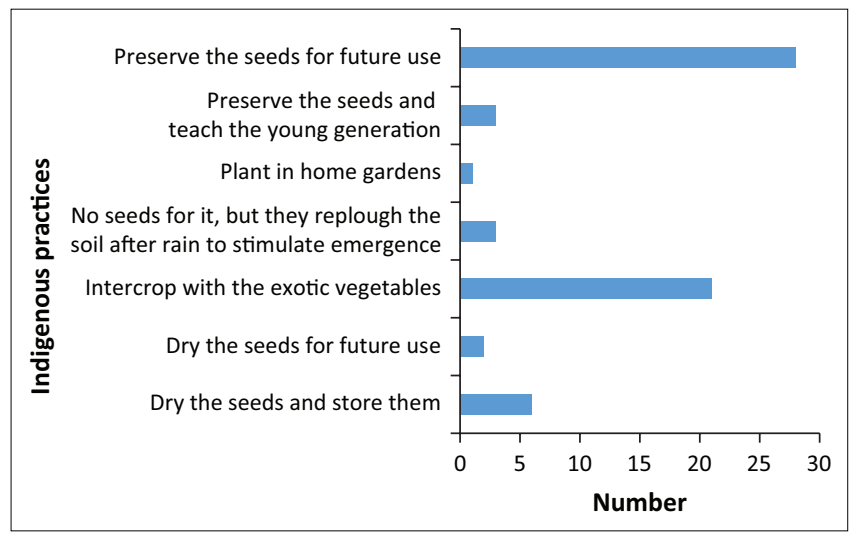

FIGURE 4: Indigenous practices used to conserve indigenous leafy vegetables. and storing them for later use, while the remaining 10\% can be preserved through freezing. Seven methods of conservation were mentioned in the present study amongst which preserving the seeds for future use was the most frequently mentioned (28 citations). This is followed by intercropping with the exotic vegetables (21 citations), while the least cited was planting the ILVs in home gardens (1 citation) (Figure 4).

\section{Availability of the indigenous leafy vegetables today as compared to the past and cause of the decline}

The results from the current study revealed that there is a high decline in both knowledge and ILVs today as compared to the past. In this study, $78 \%$ of the respondents indicated that ILVs are no longer available as compared to the past, while $22 \%$ of the respondents indicated that ILVs are still available. There are 18 reasons listed by respondents for the decline in ILVs in the study areas, among which drought is the most frequently cited (49 citations, $12.5 \%$ ) followed by the conversion of natural land for agriculture (32 citations), climate change (20 citations) and introduction of exotic vegetables (16 citations), while global warming and no market for the vegetables ( 2 citations each) are the least cited causes of decline (Table 3).

\section{Discussion}

The passing down of indigenous knowledge from grandparents to parents to children and amongst relatives and friends has been reported by Rankoana (2016). Posterity is at risk of losing this plant biodiversity information if it is left undocumented. In the present study, it was observed that elderly women were more knowledgeable about the ILVs available at villages of Mpumalanga Province because most of the community or home gardens are tendered by women. This corroborates Bvenura and Afolayan (2015) who reported that

TABLE 3: Causes of the decline in indigenous leafy vegetables.

\begin{tabular}{lcc}
\hline Cause of the decline in indigenous leafy vegetables & \multicolumn{2}{c}{ Frequency of citations } \\
\cline { 2 - 3 } & $\boldsymbol{n}$ & $\mathbf{\%}$ \\
\hline Building of roads & 9 & 2.25 \\
Changes in the soil structure and profile & 3 & 0.75 \\
Climate change & 20 & 5.00 \\
Conversion of natural land to agriculture & 32 & 8.00 \\
A decline in soil fertility & 3 & 0.75 \\
Doesn't know & 6 & 1.50 \\
Drought & 49 & 12.25 \\
Global warming & 2 & 0.50 \\
Human habitat & 25 & 6.25 \\
Introduction of exotic vegetables & 16 & 4.00 \\
Natural death & 12 & 3.00 \\
No backyard farming & 3 & 0.75 \\
No market for the vegetables & 2 & 0.50 \\
No more farming & 3 & 0.75 \\
No more rains & 14 & 3.25 \\
Not sure & 6 & 1.50 \\
Over harvesting & 13 & 3.25 \\
Reduction in soil fertility & 9 & 2.25 \\
Urbanisation & 11 & 2.75 \\
\hline
\end{tabular}


ILVs are known as women's crop in the community because they are the ones mostly responsible for their cooking and uses. This shows the diverse uses of plants in this area for both culinary and therapeutic purposes in the study area. However, our findings are the variance is that the current study revealed that 17 plant species from 15 genera as reported by 95 respondents are used for medicinal purposes in the Province, however Tshikalange et al. (2016) identified, recorded and collected a total of 82 plant species covering 77 genera and 42 families in all districts of Mpumalanga province (Gert Sibande, Nkangala and Ehlanzeni district). Results from our current study are in line with results of those of Mokganya and Tshisikhawe (2019) who reported less than 20 wild species like the current study which reported 17 wild species. The previous authors reported 13 wild vegetables that are being consumed by the Venda-speaking people of the Vhembe District Municipality, South Africa (Mokganya \& Tshisikhawe 2019). The number of ILVs reported in the study is lower than the 33 species reported at eMantlaneni village of Eastern Cape (Bvenura \& Afolayan 2015). Respondents were only able to give the local names of these vegetables. Plants are identified by their local or indigenous names all over the world. These local names are crucial in ethnobotanical studies of regions or tribes (Shosan et al. 2014).

The most representative family in the present study was Cucurbitaceae (4 species), while Amaranthaceae, Malvaceae, Asteraceae and Fabaceae each had only two species. Brassicaceae, Cleomaceae, Araceae, Convolvulaceae and Euphorbiaceae were represented by one species each. The ILVs species with the highest frequency of citations were Momordica balsamina (66 citations), Citrullus lanatus (52 citations), Amaranthus L. (42 citations), Bidens pilosa L. (33 citations) and the least being Phaseolus vulgaris, Corchorus olitorious, Beta vulgaris, Brassica oleracea and Vigna unguiculata (L.) (1 citation each). Indigenous vegetables that were most cited for their medicinal uses in the present study are Momordica balsamina (58 citations), Amaranthus L. (22 citations), Citrullus lanatus (16 citations). Furthermore, Cucurbitaceae in the present study had the highest number of species possessing medicinal properties.

Amaranth plant species were reported to provide about 34\% RDI (Recommended daily intake) of iron in adults, 320\% vitamin C, $100 \%$ calcium and $170 \%$ vitamin A (Mokganya \& Tshisikhawe 2019). Many ILVs complement and/or supplement the diet but they also play a significant therapeutic role. ILV utilisation and consumption are generally associated with the socioeconomic status of diverse ethnic groups, their dietary lifestyles and traditions. The report of Arthur, Naidoo and Coopoosamy (2012) showed that Bidens pilosa leaves possess esophageal anticancer properties. Furthermore, pharmacological studies have revealed that bioactive compounds such as tannins, terpenes, amino acids and ascorbic acids found in most of the ILVs possess antipathogenic activities (Arthur et al. 2012). Momordica balsamina reported in this study is highly acclaimed by the Zulu-speaking people in the KwaZulu-Natal province of South Africa in the management of stomach pains (Hutchings 1996). The same people also use it to manage diabetes and dress burn wounds. Due to its bitterness, the Cucurbitaceae family is perceived by the people of Vhembe district community of Limpopo province in South Africa as possessing health-promoting properties and the ability to reduce chances of hypertension and (Mokganya \& Tshisikhawe 2019). Cucurbitaceae plant species are a good source of protein and they possess various secondary metabolites that are necessary for the promotion of good health (Rajasree et al. 2016). Moringa oleifera leaves is reported to possess anti-diabetic properties, while those of Vigna unguiculata can potentially inhibit vitamin deficiency and/or malnutrition (Mokganya \& Tshisikhawe 2019). Traditional foods and herbal medicines have been shown to ameliorate COVID-19 symptoms (Saul 2020). Some reports indicate coronavirus can be treated or managed by consuming foods that are nutritionally balanced, like consuming vitamin $\mathrm{C}$ high foods in the treatment of influenza has been practiced for decades. The common colds such as Severe Acute Respiratory Syndrome Coronavirus (SARS-CoV or SARS$\mathrm{CoV}-1$ ) is a strain of coronavirus that causes severe acute respiratory syndrome (SARS) as well as SARS-CoV-2 belong to the coronavirus family; and therefore, are the same viral type (Saul 2020). Therefore, most ILVs have been proven to be rich in vitamin $C$ and their consumption may prove effective against COVID-19; although clinical studies to validate these assumptions are required.

The use of the leaves, which are often plucked off from the mother plant without uprooting the whole plant is a positive sustainable development tool and conservation of biodiversity as the plant can regrow after harvesting (De Wet, Nciki \& Van Vuuren 2013). Uncultivated ILVs mostly rely on the summer season when rainfall and other conditions are suitable for plant growth. Therefore, in regions with alternating weather condition, availability is limited thereby leaving vulnerable people without an important dietary component for most of the year (Modi, Modi \& Hendriks 2006). It is therefore important to find ways of making these vegetables available during the off-season. Although ILVs are commonly consumed fresh, sun drying is a major method of preservation when compared to other methods such as freezing. It is important to preserve ILVs for food and nutrition security during the season (Bhat, Rubuluza \& Jäger 2002). The preservation method is part of the processing method and might harm the nutrients composition so it is important to use a suitable method of preservation that will minimise loss of nutrients (Flyman \& Afolayan 2006). About $82 \%$ of the respondents in eMantlaneni village practice the drying method for preserving indigenous vegetables, however, nutrient retention using this method raises some concerns. Boiling (canning), freezing and sun drying are the common practices used traditionally to preserve ILVs (Djuikwo et al. 2011). Although these practices may not be relevant for rural communities or some urban households due to lack of resources. Djuikwo et al. (2011) found that about $65 \%$ of interviewees had no access to a freezer or fridge, thereby limiting the methods of preservation in such households. Sun drying is by far the most affordable, simplest 
and common means of preservation because of the affordability of the inputs and technologies that are required for this exercise. It is probable that the decline in ILVs consumption is linked to the ease in accessibility of exotics such as cabbage and spinach, and their availability in their fresh form all year round. Additionally, most interviewees indicated that wild vegetable species consumption is rather 'a thing of the past' and preferred exotic types because they are easier to harvest and have higher biomass yields, especially when cultivated in home gardens (Bvenura \& Afolayan 2015). Diet westernisation and the perceived rich life associated with fast foods and takeaways or modern and exotic foods are some of the reasons for the decline in ILVs consumption. Labelling leafy wild vegetable species as 'weeds' and their perception as 'backward foods' has led to their low social status as foods only consumed by the poor. Consequently, many shy away from these ILVs (Bvenura \& Afolayan 2015).

Modernisation and lifestyle changes are major contributing factors towards a decline in ILVs consumption by youths. Walking long distances to collect firewood and gather leafy wild vegetables is something, that today's youths are not keen to do (Keller, Mndiga \& Maass 2005; Shava 2000). In addition, urbanisation and education also have negative effects on the perceptions placed on ILVs primarily through the introduction of new attitudes and values amongst the youths at the expense of local cultural values and norms which remain compromised afterwards (Shava 2000). This decline in consumption of ILVs is a major concern, as they may not survive for long as a viable food source (Keller et al. 2005). The respondents in the current study disclosed that it would be incongruous to serve indigenous vegetables at social gatherings attended by visitors. According to Kgaphola and Viljoen (2000), serving ILVs during important occasions potentially lowers the social standing of the host to the guests and as such, this may not be favourable and this further highlights the negative association of these species with poverty. As reported by Van Rensburg, Van Zijl and Sonja (2007), the youths link indigenous vegetables with poverty and famine. The introduction of exotic vegetables is one of the causes of indigenous vegetable knowledge loss.

Exotic vegetables such as cabbage and spinach are broadly encouraged by agricultural extension and research, consequently leading to the complete substitution of ILVs (Keller et al. 2005). Exotic vegetables also provide monetary value for other commercial and smallholder farmers since they are easy to market and people have become very used to them. This also leads to over-cultivation and flooding of the market with exotic species and lowering their prices due to demand and the gradual shunning away from ILVs. The inability of the Government to fund researches into ILVs to help elevate the statues of these species to the statues of the exotic is also a factor to be considered and looked into because the exotic species didn't just get to their present status. It was research by their indigenous people/scientist that made the exotic species known.

\section{Conclusion}

The results of this study show that ILVs are not completely abandoned in Mpumalanga Province, especially the rural dwellers; but over the years, their use has declined. Education on the nutritional and health benefits that can be derived from the consumption of these species needs to be taken to the people by the non-governmental organisations and government amongst other stakeholders. Nutrient intake of the communities needs to be assessed in the future to enable policymakers to make informed recommendations and implement appropriate interventions that are based on scientific research outputs. The amelioration of the effects of the COVID-19 pandemic using herbs, some of which are edible (ILVs) has been reported widely. This is because of the high nutritional value of these herbs and/or indigenous vegetables as well as their therapeutic properties. To ensure that posterity does not lose out on the wide benefits of ILVs, this knowledge needs to be documented and actively taught, especially to the younger generations. The death of matriarchs and patriarchs without passing down this information, for documentation, means the death of this important knowledge and information including some traditions and ultimate cultures. Some traditional plant preservation techniques are still being practiced in these communities and this is good for plant biodiversity conservation, although more still needs to be done, possibly using modern techniques.

\section{Acknowledgements}

The authors wish to acknowledge the National Research Foundation (NRF) for financial assistance in conducting this research. The authors thank the School of Biology and Environmental Science, University of Mpumalanga for their immense contributions towards achieving this research work.

\section{Competing interests}

The authors have declared that no competing interests exist.

\section{Authors' contributions}

All the authors designed the study, coordinated data collection, carried out all the field work and drafted the manuscript.

\section{Funding information}

NRF supported this study.

\section{Data availability}

Data sharing is not applicable to this article as no new data were created or analysed in this study.

\section{Disclaimer}

The views and opinions expressed in this article are those of the authors and do not necessarily reflect the official policy or position of any affiliated agency of the authors. 


\section{References}

Adebooye, O.C. \& Opabode, J.T., 2004, 'Status of conservation of the indigenous leaf vegetables and fruits of Africa', African Journal of Biotechnology 3(12), 700-705.

Arthur, G.D., Naidoo, K.K. \& Coopoosamy, R.M., 2012, 'Bidens pilosa L.: Agricultural and pharmaceutical importance', Journal of Medicinal Plants Research 6(17) 3282-3281. https://doi.org/10.5897/JMPR12.195

Ayodele, A.E., 2005 'The medicinally important leafy vegetables of South Western Nigeria', Ethnobotanical Leaflets 2005(1), 16.

Bhat, R.B., Rubuluza, T. \& Jäger, A.K., 2002, 'The bio-diversity of traditional vegetables of the Transkei region in the Eastern Cape of South Africa', South African Journal of botany 68(1), 94-99. https://doi.org/10.1016/S0254-6299(16)30463-X

Bvenura, C. \& Afolayan, A.J., 2015, 'The role of wild vegetables in household food security in South Africa: A review', Food Research International 76, 1001-1011. https://doi.org/10.1016/j.foodres.2015.06.013

Cilliers, S.S., Janse van Vuuren, S., Kellner, K., Krüger, G.H.J., Struwig, M., Van Niekerk, C.J.G. et al., 2021, 'Hundred years of Botany at the NWU: contributions toward understanding plant and algae function, diversity and restoration in a changin environment', Bothalia-African Biodiversity and Conservation 51(1), 1-15. https:// doi.org/10.38201/btha.abc.v51.i1.2

De Wet, H., Nciki, S. \& Van Vuuren, S.F., 2013, 'Medicinal plants used for the treatment of various skin disorders by a rural community in northern Maputaland, South Africa', Journal of Ethnobiology and Ethnomedicine 9(1), 1-10. https://doi. org/10.1186/1746-4269-9-51

Djuikwo, V.N.D., Aba, R.E., Inocent, G., Carl Moses, M. \& Sherry A, T., 2011 'Determination of major carotenoids in processed tropical leafy vegetables indigenous to Africa', Food and Nutrition Sciences 2(8), 793-802. https://doi. org/10.4236/fns.2011.28109

Etkin, N.L., 2002, 'Local knowledge of biotic diversity and its conservation in rura Hausaland, Northern Nigeria', Economic Botany 56(1), 73-88.

Flyman, M.V. \& Afolayan, A.J., 2006, 'The suitability of wild vegetables for alleviating human dietary deficiencies', South African Journal of Botany 72(4), 492-497. human dietary deficiencies', South African
https://doi.org/10.1016/j.sajb.2006.02.003

Hutchings, A., 1996, Zulu medicinal plants: An inventory, University of Natal Press, Scottsville.

Keller, G.B., Mndiga, H. \& Maass, B.L., 2005, 'Diversity and genetic erosion of traditional vegetables in Tanzania from the farmer's point of view', Plant Genetic Resources 3(3), 400-413. https://doi.org/10.1079/PGR200594

Kgaphola, M.S. \& Viljoen, A.T., 2000, 'Food habits of rural Swazi households: 19391999 Part 1: Technological influences on Swazi food habits', Journal of Consume Sciences 28(2000), 68-74. https://doi.org/10.4314/jfecs.v28i1.52785

Kiambi, D. \& Atta-Krah, K., 2003, 'Plant genetic resources in the global and African setting', in Plant resources of tropical Africa, Proceedings of the First PROTA International Workshop, Nairobi, Kenya, 23-25 September 2002, pp. 33-52, PROTA Foundation, Wageningen, Netherlands.

Kimiywe, J., Waudo, J., Mbithe, D. \& Maundu, P., 2007, 'Utilization and medicinal value of indigenous leafy vegetables consumed in urban and peri-urban Nairobi', African Journal of Food, Agriculture, Nutrition and Development 7(4), 1-15.

Kumar, A., 2013, 'Ethnobotanical study of wild vegetables used by rural communities of Kannauj district, Uttar Pradesh, India', Emirates Journal of Food and Agriculture of Kannauj district, Uttar Pradesh, India', Emirates Journal of
25(10), 760-766. https://doi.org/10.9755/ejfa.v25i10.16403

Langlois-Klassen, D., Kipp, W. \& Rubaale, T., 2008, 'Communication between health providers and HIV-infected adults related to herbal medicine for AIDS treatment in western Uganda', Social Science and Medicine 67(1), 165-176. https://doi. org/10.1016/j.socscimed.2008.02.027

Martínez, G.J. \& Barboza, G.E., 2010, 'Natural pharmacopoeia used in traditional Toba medicine for the treatment of parasitosis and skin disorders (Central Chaco, Argentina)', Journal of Ethnopharmacology 132(1), 86-100. https://doi. org/10.1016/j.jep.2010.07.049

Mashile, S.P., Tshisikhawe, M.P. \& Masevhe, N.A., 2018, 'Indigenous fruit plants species of the Mapulana of Ehlanzeni district in Mpumalanga Province, South Africa', South African Journal of Botany 115, 297. https://doi.org/10.1016/j.sajb.2018.02.077
Modi, M., Modi, A. \& Hendriks, S., 2006, 'Potential role for wild vegetables in household food security: A preliminary case study in Kwazulu-Natal, South Africa', African Journal of Food, Agriculture, Nutrition and Development 6(1), 1-13. https://doi.org/10.4314/ajfand.v6i1.19167

Mokganya, M.G. \& Tshisikhawe, M.P., 2019, 'Medicinal uses of selected wild edible vegetables consumed by Vhavenda of the Vhembe District Municipality, South Africa', South African Journal of Botany 122, 184-188. https://doi.org/10.1016/j. sajb.2018.09.029

Ntiwane, B.C., 2012, 'A critical analysis of the incorporation of environmental issues into land use and planning instruments of selected municipalities of the Ehlanzeni District Municipality', Doctoral dissertation, North-West University.

Obel-Lawson, E., 2005, 'The contribution of the awareness campaign of the African leafy vegetables project to nutrition behaviour change among the Kenyan urban population: The case of Nairobi', Biodiversity International.

Odhav, B., Beekrum, S., Akula, U.S. \& Baijnath, H., 2007, 'Preliminary assessment of nutritional value of traditional leafy vegetables in KwaZulu-Natal, South Africa', Journal of Food Composition and Analysis 20(5), 430-435. https://doi. org/10.1016/j.jfca.2006.04.015

Pieroni, A., Nebel, S., Quave, C., Münz, H. \& Heinrich, M., 2002, 'Ethnopharmacology of liakra: Traditional weedy vegetables of the Arbëreshë of the Vulture area in southern Italy', Journal of Ethnopharmacology 81(2), 165-185. https://doi. org/10.1016/S0378-8741(02)00052-1

Raghuvanshi, S., Singh, R. \& Singh, R.R., 2001, 'Nutritional composition of uncommon foods and their role in meeting micronutrient needs', International Journal of Food Sciences and Nutrition 52(4), 331-335. https://doi. org/10.1080/09637480120057576

Rajasree, R.S., Sibi, P.I., Francis, F. \& William, H., 2016, 'Phytochemicals of Cucurbitaceae family - A review', International Journal of Pharmacognosy and Phytochemical Research 8(1), 113-123.

Rankoana, S.A., 2016, 'Perceptions of climate change and the potential for adaptation in a rural community in Limpopo Province, South Africa', Sustainability 8(8), 672. https://doi.org/10.3390/su8080672

Saul, A.W., 2020, 'Nutritional treatment of coronavirus', Orthomolecular Medicine News Service 16(6), 22

Shava, S., 2000, The use of indigenous plants as food by a rural community in the Eastern Cape: An educational exploration, Doctoral dissertation, Rhodes University, Grahamstown.

Shei, L.C., 2008. 'An evaluation of native West African vegetables', in Conference on International Research on Food Security, University of Hohenheim, Berlin.

Shosan, L.O., Fawibe, O.O., Ajiboye, A.A., Abeegunrin, T.A. \& Agboola, D.A., 2014 'Ethnobotanical survey of medicinal plants used in curing some diseases in infants in Abeokuta South Local Government Area of Ogun State, Nigeria', American Journal of Plant Sciences 5(21), 3258. https://doi.org/10.4236/ ajps.2014.521340

Singh, A.G., Kumar, A. \& Tewari, D.D., 2012, 'An ethnobotanical survey of medicinal plants used in Terai forest of western Nepal', Journal of Ethnobiology and Ethnomedicine 8(1), 1-15. https://doi.org/10.1186/1746-4269-8-19

Singh, H.B. \& Arora, R.K., 1978, Wild edible plants of India, ICAR, New Delhi.

Statistics South Africa, 2008, viewed 01 March 2010, from http://www.statssa.gov.za.

Tardío, J., Pardo-de-Santayana, M. \& Morales, R., 2006, 'Ethnobotanical review of wild edible plants in Spain', Botanical Journal of the Linnean Society 152(1), 27-71. https://doi.org/10.1111/j.1095-8339.2006.00549.x

Tshikalange, T.E., Mophuting, B.C., Mahore, J., Winterboer, S. \& Lall, N., 2016, 'An ethnobotanical study of medicinal plants used in villages under Jongilanga tribal council, Mpumalanga, South Africa', African Journal of Traditional, Complementary and Alternative Medicines 13(6), 83-89. https://doi.org/10.21010/ajtcam.v13i6.13

Van Rensburg W.J., Van Zijl, J.J.B. \& Sonja, L.V., 2007, 'Re-creating awareness of traditional leafy vegetables in communities', African Journal of Food, Agriculture, Nutrition and Development 7(4), 1-10.

Vorster, H.J. \& Jansen Van Rensburg, W.S., 2005, 'Traditional vegetables as a source of food in South Africa: Some experience', in African crop science conference proceedings, Vol. 7, No. pt. 2 of 3, pp. 669-671. 